\title{
Effect of Feeding Probiotics and Milk Powder Supplemented Creep Ration on the Blood Profile of Pre-Weaned Hampshire Piglets
}

\author{
Monica Tissopi $^{1^{*}}$, J. P. Bordoloi ${ }^{1}$, Anubha Baruah ${ }^{2}$, Jakir Hussain ${ }^{1}$ and Rajib Kro ${ }^{3}$ \\ ${ }^{1}$ Department of Livestock Production and Management, College of Veterinary Science, Assam \\ Agricultural University, Khanapara, Guwahati-781022, India \\ ${ }^{2}$ Department of Veterinary Physiology, College of Veterinary Science, Assam Agricultural \\ University, Khanapara, Guwahati-781022, India \\ ${ }^{3}$ Department of Livestock Production and Management, Vanbandhu College of Veterinary \\ Science and Animal Husbandry, Navsari Agricultural University, Gujarat, India \\ *Corresponding author
}

\section{A B S T R A C T}

\section{Keywords \\ Blood glucose, haemoglobin, Hampshire piglet, milk powder, probiotics, total protein.}

\section{Article Info}

Accepted: 05 April 2020 Available Online: 10 May 2020

\begin{abstract}
The experiment was conducted to study the blood profile of pre-weaned Hampshire piglets fed creep ration supplemented with probiotics and milk powder. Twenty eight numbers of piglets were selected from litters of four sows, thus forming $T_{0}, T_{1}, T_{2}$ and $T_{3}$ groups having 7 piglets each and allocated to different feeding treatment. The result of average haemoglobin $(\mathrm{Hb})(\mathrm{gm} / 100 \mathrm{ml})\left(9.70 \pm 0.66,9.85 \pm 0.65,10.10 \pm 0.59,11.45 \pm 0.91\right.$ in $\mathrm{T}_{0}, \mathrm{~T}_{1}, \mathrm{~T}_{2}$ and $\mathrm{T}_{3}$ respectively) revealed no significant difference $(\mathrm{P}<0.05)$ among the groups with a non-significantly higher $\mathrm{Hb}$ level in $\mathrm{T}_{3}$ and $\mathrm{T}_{2}$ when compared to $\mathrm{T}_{0}$ and $\mathrm{T}_{1}$. The average total protein $(\mathrm{gm} / 100 \mathrm{ml})\left(6.69 \pm 0.12,6.92 \pm 0.18,6.40 \pm 0.23\right.$ and $5.84 \pm 0.24$ in $\mathrm{T}_{0}, \mathrm{~T}_{1}, \mathrm{~T}_{2}$ and $\mathrm{T}_{3}$ respectively) were significantly higher in $\mathrm{T}_{0}$ and $\mathrm{T}_{1}$ as compared to $\mathrm{T}_{3}$. The average blood glucose $(\mathrm{mg} / 100 \mathrm{ml})(100.73 \pm 2.56,87.27 \pm 4.33,92.83 \pm 5.26$ and $92.13 \pm 2.93)$ did not differ significantly $(\mathrm{P}<0.05)$ among the groups. However, it was slightly lower in $\mathrm{T}_{1}$ followed by $T_{3}$ and $T_{2}$ as compared to $T_{0}$. The findings indicated that dietary supplementation of milk powder and probiotics alone or in combinations had a nonsignificant influence on haemoglobin, total protein and glucose levels of blood in piglets and the levels remained well within their respective normal range.
\end{abstract}

\section{Introduction}

One of the major problems in the rearing of pigs is the high mortality rate (around 20\%) up to weaning age (Backstrom, 1973). Improvement in nutrition and healthcare aimed at reducing sow's stress and piglet viability is the key to successful pre-weaning piglet management. The young pigs can grow very fast but, unfortunately, suffers from several stress factor including nutritional deprivation, environment and gastrointestinal problems (Dowarah et al., 2016). Due to larger litter sizes and increased competition 
for sow milk, nutrient availability for newlyborn pigs is often limited. Though sow milk consumption remains as the main source of nutrients for neonatal pigs, providing alternative food sources may offer numerous benefits (Sulabo, 2009). The post-weaning growth of pigs is closely related to their preweaning health status.

A gastrointestinal infection accounts for significant financial losses in addition to animal welfare concerns (Lahteinen et al., 2015). The common practice of supplementing antibiotics in livestock for improved animal performance has been condemned due to its adverse effect on animals as well as humans, the ultimate consumer of animal produce. Since then it has been the greatest challenge to farmers to rear healthy piglets devoid of antibiotics supplementation (Dowarah et al., 2016).

Thus the quest for finding ways to replace of antibiotics began with probiotics becoming suitable alternatives to antibiotics in piglets feeding strategies. FAO/WHO (2002) states that "Probiotics are mono or mixed cultures of live organisms which when administered in adequate amounts confer a health benefit to the host". Probiotics may contain one or more strains of microorganisms and may be given either alone or in combination with other additives in feed or water (Thomke and Elwinger, 1998).

Probiotics help establish a microenvironment in the gut that favours beneficial microorganisms and reduces the colonization of pathogenic bacteria (competitive exclusion) by: (1) creating a hostile environment for harmful bacteria species (through production of lactic acid, SCFA, and reduction in $\mathrm{pH}$ ); (2) competing for nutrients with undesired bacteria; (3) production and secretion of antibacterial substances (e.g. bacteriocins by Lactobacillus, Bacillus spp.); and (4) inhibition of bacterial adherence and translocation (Nurmi and Rantala, 1973; Fuller, 1989; Netherwood et al., 1999; Schneitz, 2005; Ng et al., 2009; Brown, 2011).

The best indicator of animal's wellbeing and its potential for production is its health status (Kumar et al., 2012). Madubuike and Ekenyem (2006) had stated that haematology and serum biochemistry assay of livestock suggests the physiological disposition of the animals to their nutrition. Serum biochemistry is important indicator of health and disease in animals and has become indispensible in the diagnosis, treatment or prognosis of many diseases. Determination of the serum biochemistry reflects the physiological responsiveness of the animals to its internal and external environment (Esonu et al., 2001). As such the study of blood profile of animals could be a scope to assess their physiological response to the nutritive ration provided to them.

Therefore, the present study was conducted to evaluate the effect of feeding probiotics and milk powder supplemented creep ration on the blood profile of piglets.

\section{Materials and Methods}

\section{Ethical approval}

The animal experimental protocol was approved by the Institutional Animal Ethics Committee (IAEC), Assam Agricultural University, College of Veterinary science with the number IAEC 770/ac/CPCSEA/FVSc/AAU/IAEC/17-

$18 / 535$ and carried out as per the guidelines of the Committee for the Purpose of Control and Supervision of Experiments in Animals (CPCSEA), Ministry of Environment, Forest and Climate Change, Government of India. 


\section{Experimental animals}

Seven 1-week old healthy piglets of uniform size and body weight were selected each from four different litters $(7 \times 4)$ from sows of similar parity constituting 4 groups. Each group of the experimental piglets was randomly assigned to one of the four feeding treatments viz., $\mathrm{T}_{0}$ (fed conventional creep feed), $\mathrm{T}_{1}$ (fed 5\% milk powder supplemented creep feed), $T_{2}$ (fed probiotics added @ 1g per $\mathrm{kg}$ supplemented creep feed) and $\mathrm{T}_{3}$ (fed creep feed supplemented with 5\% milk powder and probiotics @ $1 \mathrm{~g}$ per $\mathrm{kg}$ supplemented creep feed).

\section{Experimental design}

All the experimental piglets were housed at the 30-sow Teaching Unit of the Department of Livestock Production and Management and they were raised entirely on their dams' milk from birth to 7 days of age. From day- 8 onward, the piglets of $\mathrm{T}_{0}, \mathrm{~T}_{1}, \mathrm{~T}_{2}$ and $\mathrm{T}_{3}$ groups were offered respective experimental feed twice daily as per the feeding schedule up to weaning at 56 days of age. The piglets were separated from their sows daily in the morning and evening for a period of 1-2 hours following suckling and offered feed in the outdoor run and fed to appetite. The piglets were provided clean wholesome water ad libitum round the clock.

The formula of the basal conventional farm ration and also compositions of the ration, milk powder and probiotics used for the piglets are as shown in the Tables 1 and 2 respectively. The proximate analysis of the feed samples was done as per methods described in AOAC (1990).

The laboratory analyses of feed samples were done in the Department of Animal Nutrition, College of Veterinary Science, Assam Agricultural University, Khanapara, Guwahati, India.

\section{Procedure for Estimation of blood parameters}

Blood parameters were estimated at weaning on $56^{\text {th }}$ days of age of the piglets. The representative blood samples were collected from the jugular vein of the piglets using sterile syringe and needle and stored properly before examination. Laboratory analysis of blood samples were done at Department of Veterinary Physiology and T.V.C.C., College of Veterinary Science, Assam Agricultural University, Khanapara, Guwahati, India.

The estimation of hemoglobin $(\mathrm{gm} / 100 \mathrm{ml})$ was done from fresh blood just after collection by standard "Acid hematin method" using Sahli-Haemoglobinometer. The reading was made after the colour matches the standard of haemoglobinometer and the results were recorded in $\mathrm{gm} / 100 \mathrm{ml}$ blood. The Glucose $(\mathrm{mg} / 100 \mathrm{ml})$ and total protein $(\mathrm{gm} / 100 \mathrm{ml})$ estimations of the blood samples were done using commercial kits (Avantor brand).

\section{Statistical analysis}

Statistical devices like descriptive statistics, ANOVA with post hoc test (Duncan multiple range test) were used. Software package "SAS Enterprise Guide 4.3" is used to analyze the data.

\section{Results and Discussion}

The average values of haemoglobin (gm/100 $\mathrm{ml})$, total protein $(\mathrm{gm} / 100 \mathrm{ml})$ and glucose $(\mathrm{mg} / 100 \mathrm{ml})$ at weaning have been presented in Table 3.

\section{Haemoglobin}

The haemoglobin $(\mathrm{gm} / 100 \mathrm{ml})$ levels were observed to be lowest in $T_{0}$ and tended to increase slightly in $T_{3}$, followed by $T_{2}$ and $T_{1}$ 
but the difference was not significant statistically $(\mathrm{P}<0.05)$ among the treatment groups. Results of this research indicated that probiotics and milk powder supplementation did not show significant effect on $\mathrm{Hb}$ concentration of piglets. However, the slightly higher level of $\mathrm{Hb}$ in $\mathrm{T}_{3}$ and $\mathrm{T}_{2}$ groups when compared to the remaining groups $\left(\mathrm{T}_{0}\right.$ and $\left.\mathrm{T}_{1}\right)$ might be an effect of probiotics and milk powder. A plausible mechanism is that probiotics increases the bioavalibility of iron (Perez-Conesa et al., 2007) and the effect of low $\mathrm{pH}$ caused by production of organic acids by probiotics. The low $\mathrm{pH}$ can prevent the formation of complexes with low solubility and also activate phytases. The organic acids chelate with the iron and delay the gastric emptying thus increasing the absorption of iron (Sundberg, 2011). Cetin et al., (2005) found that probiotics supplementation caused statistically significant increase $(P<0.05)$ in the $\mathrm{Hb}$ values of Turkeys.

He stated in his study that dietary probiotic supplementation may prevent anaemia. The results of the current study on hematological parameter is in agreement with the findings of Rao (2007) who in his studies found no significant difference in the measured hemoglobin values between group of nursery pigs fed diets supplemented with or without Lactobacillus-based probiotics . Our results were also paralleled with that recorded by Dlamini et al., (2017) who reported that the supplementation of probiotics did not cause significant effect $(\mathrm{P}>0.05)$ on $\mathrm{Hb}$ concentration of the piglets.

In contrast to our findings, Arab et al., (2014) found that lambs receiving probiotics (Bioplus 2B) in feed had a significantly decreased $(\mathrm{P}<0.05)$ level of $\mathrm{Hb}$. The findings of the current study also disagree with that of Mohan et al., (1996) findings, who observed a significant $(\mathrm{P}<0.05)$ reduction in $\mathrm{Hb}$ content by the addition of probiotics, to a mean value of $7.9 \mathrm{~g} \%$ compared to $9.2 \mathrm{~g} \%$ in control birds. The researcher implied that this reduction may be caused by the competition of the probiotics with the host for folic acid or other nutrients.

\section{Total protein}

The result of the total protein (TP) was found to be significantly different though it was within the normal range of 5.8-8.3 $\mathrm{gm} / \mathrm{dl}$ (Boyd, 1984) in all the treatment groups. Results showed that $\mathrm{T}_{0}$ (basal diet) and $\mathrm{T}_{1}$ (milk powder) had significantly higher TP as compared to $\mathrm{T}_{3}$ (milk powder and probiotics) group of piglets. Results also showed that level of total protein was not significantly different between $T_{0}, T_{1}$ and $T_{2}$ groups indicating that supplementation of probiotics and milk powder separately had no significant effect on total protein when compared to control groups and this findings were in harmony with that recorded by Chen et al., (2005) who concluded that there was no effect of dietary probiotics feeding on total protein of growing piglets. The present findings also revealed that TP levels of $T_{2}$ and $T_{3}$ groups are not significantly different from each other but it was slightly lower in $T_{3}$ and this may be due to the combine effect of milk powder and probiotics. These findings were similar to that reported by Pollmann et al., (1980) who observed that TP level was slightly reduced with the addition of lactose in probiotics as compared to Probios feeding alone though the difference was not significant. Kumar et al., (2012) observed that serum total proteins remained within normal range and did not differ significantly among different dietary treatments with or without probiotics.

The present findings were in contrast to that reported by Bera and Samanta (2005) who found that piglets with probiotics treatment had significantly higher total protein level compared to control groups. 
Table.1 The formula of the basal conventional farm ration

\begin{tabular}{|l|c|}
\hline Name of the ingredients & Parts per Hundred \\
\hline Maize crush & 50 \\
\hline Wheat bran & 12 \\
\hline Ground nut cake(de-oiled) & 27 \\
\hline Fish meal & 8 \\
\hline Mineral mixture & 2.5 \\
\hline Salt & 0.5 \\
\hline Vitamins(A,D,E,K) & Added @ 200gm/100kg feed \\
\hline
\end{tabular}

Table.2 Composition of Farm Ration, Milk Powder (Sagar Brand) and Probiotics (Probios)

\begin{tabular}{|c|c|c|c|c|c|}
\hline \multicolumn{2}{|c|}{ Farm ration $(\%)$} & \multicolumn{2}{|c|}{ Milk powder(Per 100gm) } & $\begin{array}{l}\text { Probiotics(Viable } \\
\text { bacteria/ gm) }\end{array}$ & lactic acid \\
\hline $\begin{array}{l}\text { DM (basal } \\
\text { feed) }\end{array}$ & 95 & Energy(Kcal) & 366 & \multirow{7}{*}{$\begin{array}{l}\text { Enterococcus } \\
\text { faecium, } \\
\text { Lactobacillus } \\
\text { acidophilus, } \\
\text { Lactobacillus } \\
\text { casei and } \\
\text { Lactobacillus } \\
\text { plantarum }\end{array}$} & \multirow[t]{7}{*}{$\begin{array}{l}10 \text { million } \\
\text { CFU }\end{array}$} \\
\hline $\begin{array}{l}\text { DM(left over } \\
\text { feed) }\end{array}$ & 92 & Total fat(gm) & 1.5 & & \\
\hline $\mathbf{C P}$ & 22.1 & $\begin{array}{l}\text { Total carbohydrate } \\
(\mathrm{gm})\end{array}$ & 52 & & \\
\hline EE & 5.06 & Protein $(\mathrm{gm})$ & 35 & & \\
\hline CF & 4.75 & Sodium(mg) & 549 & & \\
\hline Total ash & 7.75 & \multirow[t]{2}{*}{ Calcium(mg) } & \multirow[t]{2}{*}{1200} & & \\
\hline NFE & 60.34 & & & & \\
\hline
\end{tabular}

Table.3 Average haemoglobin $(\mathrm{gm} / 100 \mathrm{ml})$, total protein $(\mathrm{gm} / 100 \mathrm{ml})$, glucose $(\mathrm{mg} / 100 \mathrm{ml})$ levels of piglets of different treatment groups

\begin{tabular}{|l|l|l|l|l|}
\hline \multirow{2}{*}{ Blood parameter } & \multicolumn{4}{|l|}{ Groups } \\
\cline { 2 - 5 } & $\mathrm{T}_{0}$ & $\mathrm{~T}_{1}$ & $\mathrm{~T}_{2}$ & $\mathrm{~T}_{3}$ \\
\hline Haemoglobin $(\mathbf{g m} / \mathbf{1 0 0} \mathbf{m l})$ & $9.70 \pm 0.66$ & $9.85 \pm 0.65$ & $10.10 \pm 0.59$ & $11.45 \pm 0.91$ \\
\hline Total protein $(\mathbf{g m} / \mathbf{1 0 0 m})$ & $6.69^{\mathrm{a}} \pm 0.12$ & $6.92^{\mathrm{a}} \pm 0.18$ & $6.40^{\mathrm{ab}} \pm 0.23$ & $5.84^{\mathrm{b}} \pm 0.24$ \\
\hline Glucose $(\mathbf{m g} / \mathbf{1 0 0 m l})$ & $100.73 \pm 2.56$ & $87.27 \pm 4.33$ & $92.83 \pm 5.26$ & $92.13 \pm 2.93$ \\
\hline
\end{tabular}

$(\mathrm{P}<0.05)$

${ }^{*}$ Treatment means having atleast one common superscript in a row do not differ significant

However, Arab et al., (2014) reported that lambs receiving probiotics (Bioplus 2B) in feed had a significantly decreased $(\mathrm{P}<0.05)$ level of total protein $(5.74 \pm 0.3$ and $5.58 \pm$ $0.34 \mathrm{gm} / \mathrm{dl}$ with probiotics supplementation ( 0.5 and $1 \mathrm{gm}$ per $\mathrm{kg}$ feed) as compared to control group $(6.27 \pm 1.0 \mathrm{gm} / \mathrm{dl})$.

\section{Blood glucose}

In the present study, blood glucose (GLU) levels remained within the normal range of 66.4-116.1mg/dl (Boyd, 1984) in all the groups. The blood Glucose $(\mathrm{mg} / 100 \mathrm{ml})$ levels of the piglets were found to be highest in $T_{0}$ followed by $T_{2}, T_{3}$ and $T_{1}$ groups. 
However, the statistical analysis revealed no significant difference for all the treatment groups. The average mean GLU value was slightly lower with supplementation of only milk powder $\left(\mathrm{T}_{1}\right)$ followed by probiotics with milk powder $\left(\mathrm{T}_{3}\right)$ and probiotics $\left(\mathrm{T}_{3}\right)$ as compared to control group.

Similarly, Dlamini et al., (2017) found no significant difference $(\mathrm{P}>0.05)$ in the level of blood glucose in piglets receiving diet containing probiotics when compared to the control un-supplemented group. Yadav et al., (2006) also reported that rats fed with high fructose diet, the blood glucose became lower with skim milk and dahi supplementation whereas it was significantly higher in control animals and they suggested that dahi and skim milk feeding may improve insulin resistance in the skeletal muscles and adipose tissues of rats.

Arab et al., (2014) reported that the levels of blood glucose was significantly decreased in lambs receiving probiotics (Glucose $57.00 \pm 12.0$ and $56.31 \pm 12.0 \mathrm{mg} / \mathrm{dl}$ with Bioplus 2B @ 0.5 and $1 \mathrm{gm} / \mathrm{kg}$ feed) as compared to their control group(72.71土8.6 $\mathrm{mg} / \mathrm{dl})$. On the contrary, Kumar et al., (2012) observed an increase in the levels of serum glucose in probiotic $(107.5 \pm 2.35 \mathrm{mg} / \mathrm{dl})$ treated piglet group as compared to their control group $(103.8 \pm 2.13 \mathrm{mg} / \mathrm{dl})$, though the difference was not significant. This result also did not resemble the results of Azain et al., (1996) who reported that piglets from milk replacer-supplemented litters exhibited an increase in serum glucose $(117 \mathrm{mg} / \mathrm{dl})$ as compared to control group (109mg/dl).

It can be concluded from present study that supplementation of probiotics alone or in combination with milk powder in diets have a slight but not a significant effect on the haematology and blood biochemistry of preweaned Hampshire piglets.

\section{Acknowledgement}

The authors are sincerely thankful to the Head of Departments of Veterinary Physiology, Animal Nutrition and Teaching Veterinary Clinical Complex, College of Veterinary science, Khanapara for providing the laboratory facilities during the research period. The authors would also like to extend their thanks to the Manager, 30-sow Teaching Unit for giving the permission to conduct the research in the premise and also the staffs for their full support and co-operation during the entire study period.

\section{References}

AOAC. 1990. Official methods of analysis. $15^{\text {th }}$ edn. Association of Official Analytical Chemists. Washington DC, USA, pp.152-164.

Arab, H., Mashhadi-Esmaeil, A., Rezaeian, M., and Mohtasebi, M. 2014. Effects of Bacillus Subtilis and Bacillus Lichenformis-based probiotics on performance, hematological parameters and blood metabolites in Lambs. International journal of food and nutritional sciences. 3(4): 8-15.

Azain, M.J., Tomkins, T., Sowinski, J.S., Arentson, R.A., and Jewell, D.E. 1996. Effect of supplemental pig milk replacer on litter performance: Seasonal variation in response. Journal of Animal Science. 74(9): 2195-2202.

Backstrom, L. 1973. Environment and health in piglet production. A field study of incidences and correlations. Acta Vet. Scand. 41: 1-240.

Bera, J. and Samanta, G. 2005. Effect of feeding probiotics on the performance of piglets. Indian Journal of Animal Nutrition. 22(3): 156-159.

Boyd, J.W. 1984. The interpretation of serum biochemistry test results in domestic animals. Veterinary Clinical 
Pathology. 13(2): 7-14.

Brown, M. 2011. Modes of action of probiotics: recent developments. Journal of Animal and Veterinary Advances. 10: 1895-1900.

Cetin, N., Guclu, B.K., and Cetin, E. 2005. The effects of probiotic and mannanoligosaccharide on some haematological and immunological parameters in turkeys. J. Vet. Med. 52(6): 263-267.

Chen, Y.J., Son, K.S., Min, B.J., Cho, J.H., Kwon, O.S., and Kim, I.H. 2005. Effects of dietary probiotic on growth performance, nutrients digestibility, blood characteristics and fecal noxious gas content in growing pigs. Asian Australasian Journal of Animal Sciences. 18(10): 1464-1468.

Dlamini, Z.C., Langa, R.L.S., Aiyegoro, O.A., and Okoh, A.I. 2017. Effects of probiotics on growth performance, blood parameters, and antibody stimulation in piglets. South African Journal of Animal Science. 47(6): 766-775.

Dowarah, R., Verma, A.K., and Agarwal, N. 2016. The use of Lactobacillus as an alternative of antibiotic growth promoters in pigs: A review. Animal Nutrition. 3(1):1-6.

Esonu, B.O., Enenalom, O.O., Udedibie, A.B.I, Herbert, U., Ekpor, C.F., Okoli, I.C., and Iheukwumere, F.C. 2001. Performance and blood chemistry of weaner pigs fed raw mucuna (velvef bean) meal. Trop. Anim. Prod. Invest. 4: 49-55.

FAO/WHO. 2002. Probiotics in food health and nutritional properties. FAO Food and Nutrition Paper. Rome, Italy, pp. 25.

Fuller, R. 1989. Probiotics in man and animals. Journal of Applied Bacteriology. 66: 65-378.

Kumar, S., Verma, A.K., Mondal, S.K.,
Gupta, M., Patil, A.K., and Jangir, B.L. 2012. Effect of live Saccharomyces cerevisiae feeding on serum biochemistry in early weaned cross bred piglets. Veterinary World. 5(11): 663-666.

Lahteinen, T., Rinttila, T., Koort, J.M.K., Kant, R., Levonen, K., Viljanen, M.J., Bjorkroth, J., and Palva, A. 2015. Effects of a multispecies Lactobacillus formation as a feeding supplement on the performance and immune function of piglets. Livestock Science. 180:164- 171.

Madubuike, F.N., Ekenyem, B.U. 2006. Haematology and Serum Biochemistry characteristics of broiler chicks fed varying dietary levels of Ipomoea asarifolia Leaf Meal. International Journal of Poultry Science. 5: 9-12.

Mohan, B., Kadirvel, R., Natarajan, A., and Bhaskaran, M. 1996. Effect of probiotic supplementation on growth, nitrogen utilisation and serum cholesterol in broilers. British Poultry Science. 37(2): 395-401.

Netherwood, T., Gilbert, H.J., Parker, D.S., and O'Donnell, A.G. 1999. Probiotics shown to change bacterial community structure in the avian gastrointestinal tract. Applied and Environmental Microbiology. 65: 5134-5138.

Ng, S.C., Hart, A.L., Kamm, M.A., Stagg, A.J., and Knight, S.C. 2009. Mechanisms of action of probiotics: recent advances. Inflammatory Bowel Diseases. 15: 300-310.

Nurmi, E., and Rantala, M. 1973. New aspects of Salmonella infection in broiler production. Nature. 241: 210211.

Perez-Conesa, D., Lopez, G., and Ros, G. 2007. Effect of probiotic, prebiotic and synbiotic follow-up infant formulas on iron bioavailability in rats. Food Science and Technology 
International. 13(1): 69-77.

Pollmann, D.S., Danielson, D.M., and Peo, E.R. 1980. Effects of Microbial Feed Additives on Performance of Starter and Growing-finishing Pigs. Journal of Animal Science. 51(3): 577-581.

Rao, S.O. 2007. Effects of dietary supplementation of lactobacillusbased probiotics on growth and gut environment of nursery pigs (Doctoral dissertation). Master of Animal Science Thesis, Graduate Faculty of Texas Tech University.

Schneitz, C. 2005. Competitive exclusion in poultry -30 years of research. Food Control 16: 657-667.

Sulabo, R.C. 2009. Influence of creep feeding on individual consumption characteristics and growth performance of neonatal and weanling pigs. Ph.D. Dissertation, Department of Animal Sciences and Industry, College of Agriculture, Kansas State University.

Sundberg, M. 2011. Iron bioavailability and pro-and prebiotics. Independent project in Food science. Bachelor's Programme - Food \&Health. Swedish University of Agricultural Sciences Department of Food Science, Uppsala.

Thomke, S., and Elwinger, K.1998. Growth promotants in feeding pigs and poultry. II. Mode of action of antibiotic growth promotants. Annales De Zootechnie. 47: 153-167.

Yadav, H., Jain, S., and Sinha, P.R. 2006. Effect of skim milk and dahi (Yogurt) on blood glucose, insulin, and lipid profile in rats fed with high fructose diet. Journal of Medicinal Food. 9(3): 328-335.

\section{How to cite this article:}

Monica Tissopi, J. P. Bordoloi, Anubha Baruah, Jakir Hussain and Rajib Kro. 2020. Effect of Feeding Probiotics and Milk Powder Supplemented Creep Ration on the Blood Profile of PreWeaned Hampshire Piglets. Int.J.Curr.Microbiol.App.Sci. 9(05): 123-130.

doi: https://doi.org/10.20546/ijcmas.2020.905.013 